\title{
Growth, Nutrient Uptake, and Foliar Gas Exchange in Pepper Cultured with Un-composted Fresh Spent Mushroom Residue
}

\author{
He ZHU, Shujie ZHAO, Jingmin YANG, Lingquan MENG, \\ Yunqing LUO*, Bo HONG, Wei CUI, Minghui WANG, Wencong LIU** \\ Jilin Agricultural University, College of Resources and Environment, Changchun 130118,China; zhubw15@163.com;sjzhaom@163.com; \\ yangjm973@sina.com; lingqmeng@126.com;yunqingluo@sina.cn (*correspondingauthor); bohong92@sina.com; \\ xiaocui973@163.com;drwangmb@sina.com; liwwencong863@163.com $\left({ }^{* *}\right.$ correspondingauthor $)$
}

\begin{abstract}
Spent mushroom substrate (SMS) can be used as the component of growing medium for the culture of crop plants. Fresh SMS may have the potential as an alternative to peat to raise horticultural plants. In this study, five container media characterized by the proportions of SMS to commercial peat in $0 \%$ (control), $25 \%, 50 \%, 75 \%$, and $100 \%$ were used to raise pepper (Capsicum annum L.) plants. Initial SMS was found to have low available nitrogen $(\mathrm{N})$ content $\left(<20 \mathrm{mg} \mathrm{kg}^{-1}\right) b_{\mathrm{t}}$ moderate extractable phosphorus $(\mathrm{P})$ content $\left(900 \mathrm{mg} \mathrm{kg}^{-1}\right)$. In the second month photosynthetic rate was found to decline in the $75 \%$ treatment. At harvest in the third month, plants in the $100 \%$ treatment nearly died out. The $25 \%$ treatment resulted in the highest height $(19 \mathrm{~cm})$ and diameter growth $(0.3 \mathrm{~cm})$, shoot $(0.6 \mathrm{~g})$ and root biomass accumulation $(0.13 \mathrm{~g})$, fruit weight $(3 \mathrm{~g})$, and shoot carbohydrate content $\left(98 \mathrm{mg} \mathrm{g}^{-1}\right)$, but lowest foliar acid phosphatase activity $\left(30 \mu \mathrm{g} \mathrm{NPP} \mathrm{g}^{-1} \mathrm{FW} \mathrm{min}^{-1}\right)$. With the increase of SMS proportion in the substrate, the medium $\mathrm{pH}$ and electrical conductance (EC) increased with the decrease of foliar size. The available $\mathrm{N}$ and $\mathrm{P}$ contents in the substrates showed contrasting relationship with $\mathrm{N}$ and $\mathrm{P}$ contents in pepper plants. Therefore, fresh SMS cannot be directly used as the substrate for the culture of pepper plants. According to our findings fresh SMS was recommended to be mixed in the proportion of $25 \%$ with commercial peat for the culture of horticultural plants.
\end{abstract}

Keywords: nutrient utilization; solid waste; spent mushroom residue; un-compost; weathered material

\section{Introduction}

Currently, mushroom production is one of the largest solid-state fermentation industries all over the world (Soccol and Vandenberghe, 2008). After mushroom is harvested, the spent residue is considered "spent out" and abandoned as weathered fresh substrate, generating a by-product of mushroom cultivation. Every production of $1 \mathrm{~kg}$ of mushroom would generate $2.5-5 \mathrm{~kg}$ of spent mushroom substrate (SMS) (Semple et al., 2001; Ünal, 2015). A huge amount of SMS is produced every year in the world: 0.2 million tons in Turkey, 0.99 million tons in Spain, and 38.93 million tons in China (FAO, 2016). To properly dispose SMS can not only increase the income of byproduct of mushroom industry but also eliminate the potential environmental contamination by disposable manner.

SMS is usually utilized as the spent mushroom compost (SMC). SMC can function as an amendment to improve soil physical properties, which benefits from decreased bulk density, reduced clod, mitigatory crust-formation, promoted infiltration, enhanced water content (Stewart $e t$ al., 1998), and increased aggregate stability (Stewart $e t$ al., 1998; Curtin and Mullen, 2007). SMC contains abundant content of nutrients that is generally harmless to plants (Tam and Wang, 2015; Paredes et al., 2016). SMC is also rich in humus content, which can provide nutrients for plant growth in a long term as slow-release source (Kadiri and Mustapha, 2010). SMC application to soils can also improve nutrient availability for vegetable growth (Rhoads and Olson, 1995; Wuest et al., 1995). In addition, the porosity of SMC would probably favour the root develop to increase the efficiency of nutrient and water uptake. These properties all contribute to the suggestion of SMC as one component in the growing media for crop plant culture (Chong et al., 1994; Tam and Wang, 2015; Nguyen and Wang, 2016).

Currently, peat is the main component in the commercial substrates for the cultivation of containerized plants globally (Ribeiro et al., 2007). The heavy extraction of peat source for the usage of commercial substrate for 
228

horticultural plants has resulted in the wetland depletion. This also causes the problems of non-renewable source loss from degraded wetland ecosystem and $\mathrm{CO}_{2}$ permission through peat decomposition (Bustamante et al., 2008). Therefore, SMC has been aroused as an alternative to the commercial peat substrate (Kandemir et al., 2009; Ünal, 2015; Zhang et al., 2012, 2013). The use of SMC in the container substrate can efficiently inhibit the pathogen damage on horticultural crops (Segarra et al., 2007; Chen et al., 2015), promote nutrient uptake (Paredes et al., 2016; Sönmez et al., 2016), and promote crop growth (Ünal, 2015). However, the high $\mathrm{pH}$ value and electrical conductance (EC) prevent SMS to be used as the main component in the substrate (Szmidt and Chong, 1995; Gonani $e t$ al., 2011). Therefore, SMC was usually applied to replace some peat in the substrate where horticultural plant tended to respond in better germination and growth in the lower SMS proportion of 20 30 \% (Chong et al., 1994; Khan et al., 2006; Medina et al., 2009; Gonani et al., 2011; Kwack et al., 2012).

Fresh SMSs are those being weathered but have not been composted. The application of fresh SMS requires less time consumption, site occupation, labour forces, and additional input compared to the compost. Like SMC, the fresh SMS can also amend soils thorough decreasing compactness (Peregrina et al., 2012; Kato et al., 2013) and increasing porosity and fractal dimension (Nakatsuka et al., 2016). However, fresh SMS is usually characterized by high salt content therefore tends to be unsuitable as the main component of growing media (Chong et al., 1994). However, little is known about the effect of mixed fresh SMS and peat on containerized crops.

Pepper (Capsicum annuum L.) is an important horticultural vegetable in the world (Marín et al., 2014). Globally the cultivation of pepper plants occupied about 0.53 million ha with the total production of 0.55 ton (FAO, 2016). By 2016, Asia has the largest area for pepper crop cultivation of 0.45 million ha, which accounted for $85 \%$ of the whole world area (FAO, 2016). During the culture of pepper plants, the involvement of SMC in the medium can effectively suppress the fungal disease (Marín et al., 2014), enhance the vegetative growth (Ahlawat et al., 2007), and promote the fruit quality (Eudoxie et al., 2014). It was also indicated that un-composted solid-waste was more efficient to promote the pepper growth than aerated composted one (Marín et al., 2014). The effect of fresh SMS substrate on pepper may contain more uncertainty than expected because pepper is salt-sensitive (Medina et al., 2009).

In this study, pepper plants were cultured in a controlled environment with the media of commercial peat and fresh SMS in different proportions. The main objective of this work was to quantify the chemical properties of the substrate and the plant quality and fruiting performance. We also determined physiological parameters to detect the potential mechanism for plant response. It was hypothesized that: (i) both growth and fruiting performance were best in the treatment with low proportion of fresh SMS, which resulted in (ii) higher photosynthesis and gas exchange and (iii) better nutrient availability.

\section{Materials and Methods}

\section{Study site and condition}

The present study was conducted in a growth chamber at the platform of combined manipulations of illumination and fertility on plant growth regulation $\left(43^{\circ} 59^{\prime} 46^{\prime \prime} \mathrm{N}, 125^{\circ} 23^{\prime} 34^{\prime \prime}\right.$ E) (Zhilunpudao Agric. S\&T Co., Ltd., Changchun, China). Throughout the experiment all environmental factors of light, temperature and moisture were manually controlled to the best condition for plant growth. Light was supplied for $16 \mathrm{~h}$ per day by artificial illumination of high-pressure sodium (HPS) lamps to the intensity of 4000-5000 lx with the spectrum of $43.9 \%$ red $(600-700 \mathrm{~nm}), 54.7 \%$ green $(500-600 \mathrm{~nm})$, and $1.4 \%$ blue $(400-500 \mathrm{~nm})$. This illumination condition has been proven to favor plant growth even for slowly growing species (Wei et al., 2013; Zhu et al., 2016). Under this illumination condition, the photosynthetic photon flux density (PPFD) was measured to be $72-73 \mu \mathrm{mol} \mathrm{m}^{-2} \mathrm{~s}^{-1}$ at the tip of pepper shoot. Temperature was measured to be $16.8 / 31.7^{\circ} \mathrm{C}$ (night/day). The relative humidity $(\mathrm{RH})$ ranged between $49 \%$ and $94 \%$.

\section{Experiment design}

The experiment was conducted as a completely randomized design with different media substrate proportions of fresh SMS and commercial peat. SMS was added to peat in proportions of $100 \%, 75 \%, 50 \%$, and $25 \%$ $(\mathrm{v} / \mathrm{v})$. The peat substrate with $0 \%$ proportion $(\mathrm{v} / \mathrm{v})$ of SMS added was tested as the control. Each treatment was replicated for three times. SMS was obtained from a local mushroom factory in Changchun after the production of Pleurotus eryngii. The raw material of SMS included 20\% cottonseed hull, $20 \%$ wood bits, $24 \%$ corncobs, $20 \%$ brans, $5 \%$ corn flour, $2 \%$ lime carbonate, $1 \%$ gypsum powder, and $8 \%$ bean pulp. Before the experiment, SMS were prepared to be oven-dried at $45^{\circ} \mathrm{C}$ for $2 \mathrm{~d}$. Dried $S M S$ were ground to pass 5-mm sieve to generate homogeneous granules. The commercial peat was supplied by a local peat-manufacturer (Mushro-Dust, Chuangfeike S\&T Co., Ltd., Jingyu, Baishan, China). This peat production was mainly manufactured by peat ( $80 \%)$, perlite (15\%), and vermiculite (5\%). Annual sale number of this commercial peat was around 0.55 million, $20 \%$ of which were sold for the culture of pepper plants. Both chemical nutrients and nutrientrelease controller were added to the peat substrate to guarantee plants can be fed by nutrients for at least three months. Chemical properties of the substrate in each treatment are shown in Table 1.

\section{Pepper plant culture}

On 23 April 2017, pepper seeds were sown in a seeding tray filled with pure peat. On 14 May 2017, germinant seedlings were transplanted to planting trays. There were 32 plug holes ( $4 \times 8$ spacing) in the tray with each hole of $13 \mathrm{~cm}$ in height and $7 \mathrm{~cm}$ in diameter. Before planting, seedlings were firstly screened for uniform size to eliminate the possible difference among plant units. Seedlings in one tray were assigned as a treatment unit and three trays were arranged as replicates. Trays were placed in tanks $(35 \mathrm{~cm} \times$ $55 \mathrm{~cm}$, width $\times$ length) to enable the sub-irrigation, which 
has been fully proven to ensure the root moisture with uniform water supply in the controlled environment (Wang et al., 2017; Zhao et al., 2017). During the experimental stage, seedlings were watered every two days by maintaining the water table in the tank at the height of about $4 \mathrm{~cm}$. All Seedling trays were rearranged after each irrigation manipulation to eliminate the possible edge effect.

\section{Measurement of photosynthesis and gas exchange}

On 17 July 2017 when leaves at the top of the stem had fully expanded, four seedlings in one tray were randomly chosen and measured for photosynthesis and gas exchange using Li-Cor 6400 portable photosynthetic detector ( $\mathrm{Li}$ Cor Co., Lincoln, U.S.A.). Fully expanded leaves at the top of the stem were chosen for measurement. During the measurement, the PPFD was controlled at $1000 \mu \mathrm{mol} \mathrm{m} \mathrm{m}^{-2} \mathrm{~s}$ 1 , while the carbon dioxide $\left(\mathrm{CO}_{2}\right)$ concentration was controlled at $400 \mu \mathrm{mol} \mathrm{mol} \mathrm{m}^{-1}$. Because seedlings were cultured under uniformly artificial lighting environment, the measuring time was not stipulated to any specific period of the day. However, all measured were finished in four hours from 12:30 to 16:30. Water use efficiency (WUE) was calculated as the ratio of photosynthetic rate to transpiration rate (Guo et al., 2016).

\section{Seedling harvest and determination}

On 17 August 2017, after three months' culture two trays of seedlings in the $100 \%$ SMS treatment died out leaving quite few seedlings alive in the last tray (Fig. 1). Thereafter, the experiment was terminated and all seedlings were sampled in the rest of treatments. Ten seedlings were randomly sampled from one tray and measured for height, diameter, boll number, fruit number, and fruit weight. The results of the ten seedlings were averaged as the value for one tray as one replicate of the treatment. Thereafter, the ten seedlings were grouped into two halves.

The first half of five seedlings was divided into shoot and root parts and measured for biomass after drying in the ventilated oven at $70{ }^{\circ} \mathrm{C}$ for $3 \mathrm{~d}$. Dried samples were ground to pass 2-mm sieve and determined for sugar, starch, N, and $\mathrm{P}$ concentrations. Soluble sugars (glucose, fructose and sucrose) and starch concentrations were determined by the colorimetric method (Wei et al., 2014) using a spectrophotometer at $490 \mathrm{~nm}$ (UV-Visible 8453, Agilent Technologies Inc., Santa Clara, CA, USA). Briefly, 0.5-g sample was added to $50 \mathrm{~mL}$ of distilled water, steamed by the high pressure for two hours and determined for the concentration of soluble sugars; thereafter the residual was washed by distilled water, oven-dried, added to hydrochloric acid, extracted in boiling water bath for eight hours, added with sodium hydroxide solution and determined for starch concentration. Total $\mathrm{N}$ and $\mathrm{P}$ concentrations were determined with the modification of the method described by Li et al. (2017). The $0.2 \mathrm{~g}$ sample was digested in $5 \mathrm{~mL}$ mixture of hydrogen peroxide and sulfuric acid. The digestion solution was diluted to $50 \mathrm{~mL}$ with deionized water. Total $\mathrm{N}$ concentration was determined using the Kjeldahl method. Total P concentration was determined by the Molybdenum-anticolorimetry method.

The other half of five seedlings was used for the measures on foliar size and green degree and the determination of enzyme activities of acid phosphatase (ACP) and glutamine synthetase (GS). Four leaves were randomly collected from one seedling and scanned for the projected image at the dpi of 118.11 pixels $\mathrm{cm}^{-1}(\mathrm{HP}$ Deskjet 1510 scanner, HP Inc., Palo Alto, CA, USA). The leaf image was transformed to the gif format by Photoshop CS V 8.0 (Adobe, San Jose, CA, USA) and removed for all background colours. The leaf-pattern zone was targeted by one marquee and opened as an intact histogram. The leaf area was calculated by the total pixels of the histogram divided by the square of dpi. The foliar green degree was given by the averaged value of the green channel from the RGB panel in the histogram.

\section{Statistical analysis}

The chemical properties in substrates, photosynthesis, and gas exchange were analyzed for all five treatments. Because seedlings in the $100 \%$-SMS treatment died out a harvest, data about growth, biomass, physiology, carbohydrate, and nutrient content were analyzed for the four treatments in SMS proportions of 0\% (control), 25\%, $50 \%$, and $75 \%$. All data were tested for the normality and the homogeneous variances and no data needed to be transformed. Data were analyzed using SAS software (SAS Institute Inc., NC, USA). The analysis of variance (ANOVA) was conducted to detect the effect of treatments on parameters using the GLM procedure. When the significant effect was indicated by ANOVA at the 0.05 level, values were compared and ranged by Tukey test. The relationship between the chemical properties of the substrates and $\mathrm{N}$ and $\mathrm{P}$ contents and concentrations in shoot and root parts were analyzed using the Pearson correlation with the CORR procedure.

Table 1. Chemical properties of the substrates with fresh spent mushroom substrate mixed with commercial peat in different proportions ( $\mathrm{v} / \mathrm{v}$ )

\begin{tabular}{|c|c|c|c|c|c|}
\hline Treatment & $\begin{array}{l}\mathrm{NH}_{4}^{+}-\mathrm{N} \\
\left(\mathrm{mg} \mathrm{kg}^{-1}\right)\end{array}$ & $\begin{array}{l}\mathrm{NO}_{3}{ }^{-}-\mathrm{N} \\
\left(\mathrm{mg} \mathrm{kg}^{-1}\right)\end{array}$ & $\begin{array}{l}\mathrm{PO}_{4}^{3-}-\mathrm{P} \\
\left(\mathrm{mg} \mathrm{kg}^{-1}\right)\end{array}$ & $\mathrm{pH}$ & $\begin{array}{c}\mathrm{EC} \\
\left(\mathrm{d} S \mathrm{~m}^{-1}\right)\end{array}$ \\
\hline $0 \%$ & $124.74 \pm 4.92 \mathrm{a}$ & $152.51 \pm 8.63 a$ & $232.29 \pm 18.26 \mathrm{e}$ & $4.29 \pm 0.05 \mathrm{~d}$ & $0.31 \pm 0.20 c$ \\
\hline $25 \%$ & $121.75 \pm 2.02 \mathrm{a}$ & $137.63 \pm 3.56 \mathrm{a}$ & $364.88 \pm 3.45 \mathrm{~d}$ & $4.48 \pm 0.06 \mathrm{~cd}$ & $0.99 \pm 0.12 b$ \\
\hline $50 \%$ & $113.33 \pm 1.66 \mathrm{a}$ & $49.11 \pm 4.08 b$ & $510.52 \pm 8.78 c$ & $4.66 \pm 0.05 c$ & $1.54 \pm 0.23 b$ \\
\hline $75 \%$ & $74.35 \pm 10.79 b$ & $36.96 \pm 5.70 \mathrm{~b}$ & $637.86 \pm 10.43 b$ & $5.10 \pm 0.19 b$ & $2.35 \pm 0.29 \mathrm{a}$ \\
\hline $100 \%$ & $19.52 \pm 8.18 \mathrm{c}$ & $11.07 \pm 4.13 c$ & $910.01 \pm 13.67 \mathrm{a}$ & $5.66 \pm 0.08 \mathrm{a}$ & $2.74 \pm 0.09 a$ \\
\hline M.S. & 5976.84 & 12078.55 & 20423.17 & 0.94 & 2.94 \\
\hline$F$ value & 124.79 & 353.14 & 1274.12 & 79.51 & 66.17 \\
\hline $\operatorname{Pr}>F$ & $<0.0001$ & $<0.0001$ & $<0.0001$ & $<0.0001$ & $<0.0001$ \\
\hline
\end{tabular}




\section{Results}

\section{Chemical properties in substrates}

The treatments of different proportions of SMS in the substrate resulted in significantly different changes of chemical properties of $\mathrm{NH}_{4}^{+}-\mathrm{N}, \mathrm{NO}_{3}^{-}-\mathrm{N}, \mathrm{PO}_{4}^{3-}-\mathrm{P}, \mathrm{pH}$, and EC (Table 1). Generally, with the increase of SMS proportion in the substrate, $\mathrm{NH}_{4}^{+}-\mathrm{N}$ and $\mathrm{NO}_{3}{ }^{-} \mathrm{N}$ concentrations tended to decline but the $\mathrm{PO}_{4}^{3-}-\mathrm{P}$ concentration, $\mathrm{pH}$, and $\mathrm{EC}$ showed increasing trends. The $\mathrm{NH}_{4}^{+}-\mathrm{N}$ concentration did not change with the SMS proportion increasing from $0 \%$ to $50 \%$ but significantly declined since the $75 \%$ proportion to the lowest value in the $100 \%$ SMS proportion treatment. The $\mathrm{NO}_{3}^{-}-\mathrm{N}$ concentration declined by about $70 \%$ in the $50 \%$ and $75 \%$ treatments than that in the $0 \%$ and $25 \%$ treatments and also showed lowest value in the $100 \%$ treatment. The $\mathrm{PO}_{4}^{3-}-\mathrm{P}$ concentration was lowest in the control and highest in the $100 \%$ treatment, while the latter increased by $290 \%$ than the earlier. Compared to $\mathrm{pH}$ and $\mathrm{EC}$ values in the control, those in the $100 \%$ treatment were increased by $32 \%$ and $820 \%$, respectively.

\section{Pepper growth, biomass and fruiting performance}

Because pepper plants in the $100 \%$ treatment died out at harvest (Fig. 1), results were not analyzed for this treatment. Height and diameter growth both tended to increase from the control to the $25 \%$ treatment thereafter declined in the

Table 2. Growth and fruiting performance of pepper plants in fresh spent mushroom substrate mixed with commercial peat in different proportions $(\mathrm{v} / \mathrm{v})$

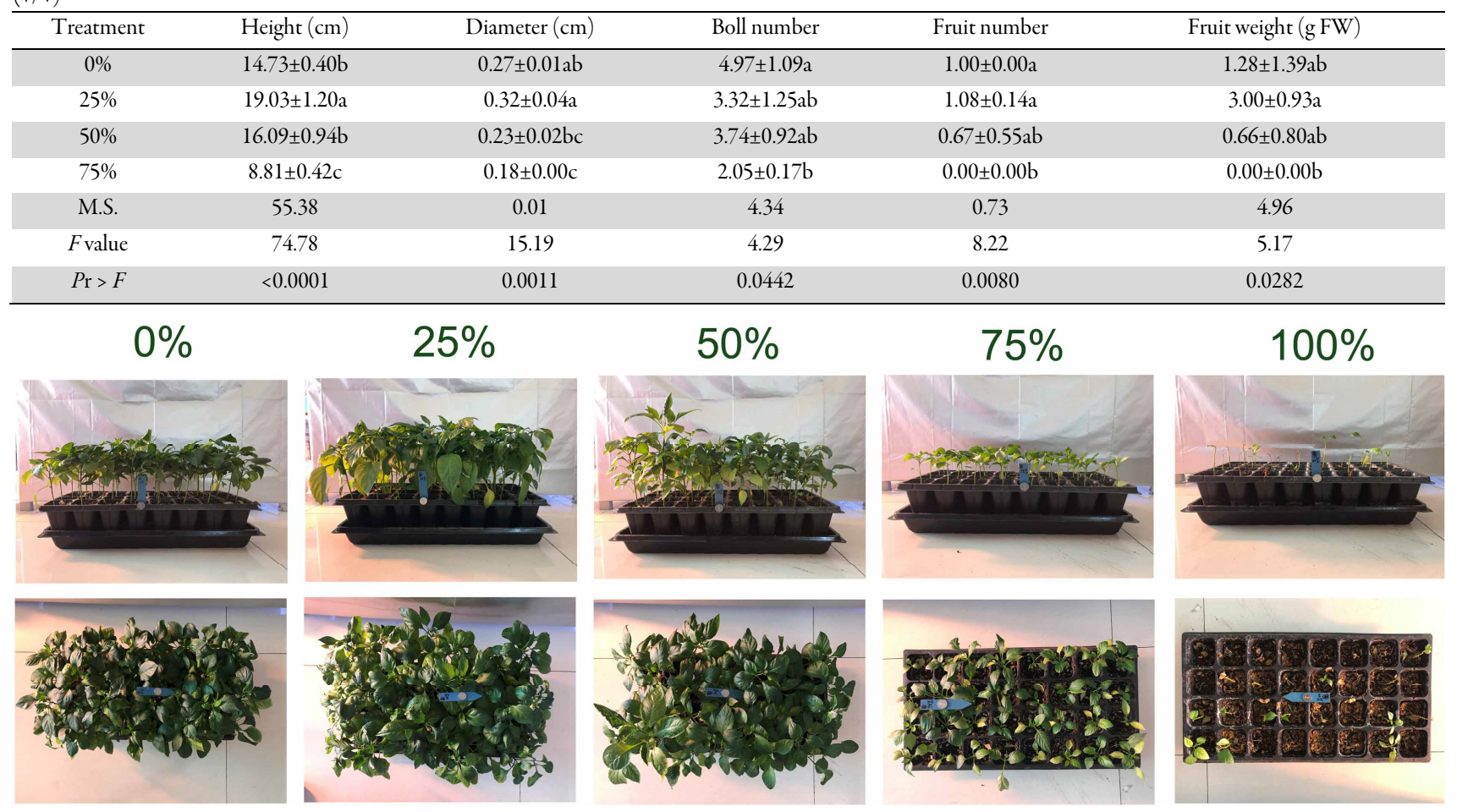

Fig. 1. The appearance of pepper (Capsicum annuum L.) plants cultured in the media mixed with commercial peat and fresh spent mushroom substrate (SMS) in proportions of $0 \%$ (control), 25\%, 50\%, 75\%, and 100\%. Seedlings in the $100 \%$ SMS substrate treatment nearly died out
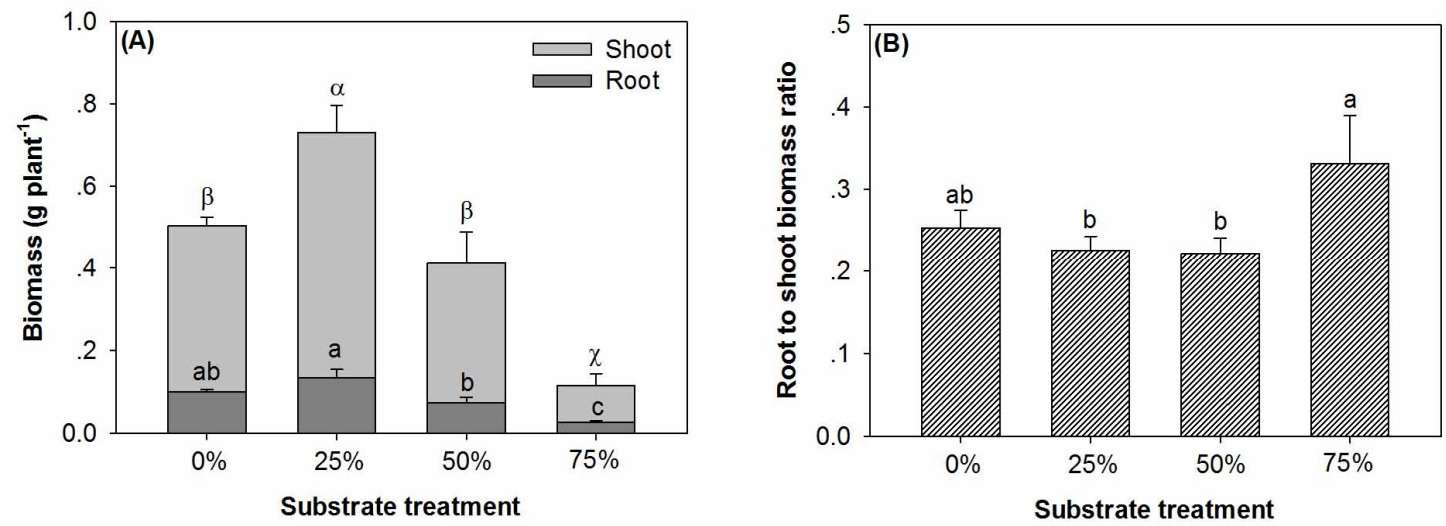

Fig. 2. Biomass accumulation in shoot and root parts (A) and root to shoot biomass ratio (B) in pepper (Capsicum annuum L.) plants cultured in the media mixed with commercial peat and fresh spent mushroom substrate (SMS) in proportions of $0 \%$ (control), 25\%, 50\%, and 75\%. Different letters indicate significant difference in Tukey test at $\alpha=0.05$. In the cell A, letters of $\alpha$, $\beta$, and $\chi$ indicate difference for shoot part; letters of $a, b$, and $c$ indicate difference for root part 
$50 \%$ and $75 \%$ treatments (Table 2). Boll number decreased in the $75 \%$ treatment by $59 \%$ than in the control. Fruit number and weight in the $75 \%$ treatment both decreased by $100 \%$ compared to those in the $25 \%$ treatment.

Both shoot and root biomass tended to show highest value in the $25 \%$ treatment and be lowest in the $75 \%$ treatment (Fig. 2A). Compared to the biomass in the $25 \%$ treatment, biomass in the shoot and root parts in the $75 \%$ decreased by $85 \%$ and $79 \%$, respectively. In contrast, the root to shoot biomass ratio $(\mathrm{R} / \mathrm{S})$ tended to increase from the proportion of SMS in the substrate (Fig. 2B). Compared to the $\mathrm{R} / \mathrm{S}$ in the $25 \%$ and $50 \%$ treatments, that in the $75 \%$ treatment was increased by $32 \%$.

\section{Photosynthesis and gas exchange}

With the increase of SMS proportion in substrate, the photosynthetic rate did not change from the $0 \%$ to the $50 \%$ treatments and decreased by $5 \%$ in the $75 \%$ treatment (Table 3). However, the conductance and transpiration rate were not affected by SMS proportion treatments. The WUE was highest in the $75 \%$ treatment, which was higher by $354 \%$ than that in the $0 \%, 25 \%$, and $50 \%$ treatments.

\section{$N$ and $P$ concentrations and contents}

With the increase of SMS proportion in the substrate, $\mathrm{N}$ and $\mathrm{P}$ concentrations showed contrasting responses (Fig. 3). Shoot and root $\mathrm{N}$ concentrations generally showed the decreasing trends but $\mathrm{P}$ concentration showed the increasing trend. Compared to shoot $\mathrm{N}$ concentration in the control, that in the $25 \%$ treatment declined by $24 \%$ $(P=0.0003)$ (Fig. 3A). In the $75 \%$ treatment, shoot $\mathrm{N}$ concentration declined to be $68 \%$ of that in the control. Root $\mathrm{N}$ concentration did not change from the $0 \%$ to the $50 \%$ treatments, but declined by $33 \%$ in the $75 \%$ treatment than in the $50 \%$ treatment $(P=0.0015)$ (Fig. 3A). Shoot $P$ concentration decreased in the $25 \%$ treatment compared to that in the control by $18 \%$ than increased in the $50 \%$ and $75 \%$ treatments $(P<0.0001) \quad$ (Fig. 3B). Root $P$

Table 3. Photosynthesis and gas exchange of pepper plants in fresh spent mushroom substrate mixed with commercial peat in different proportions $(\mathrm{v} / \mathrm{v})$

\begin{tabular}{|c|c|c|c|c|}
\hline Treatment & $\begin{array}{l}\text { Photosynthetic rate } \\
\left(\mu \mathrm{mol} \mathrm{CO} 2 \mathrm{~m}^{-2} \mathrm{~s}^{-1}\right)\end{array}$ & $\begin{array}{c}\text { Conductance } \\
\left(\mu \mathrm{ol} \mathrm{H} \mathrm{O} \mathrm{m}^{-2} \mathrm{~s}^{-1}\right)\end{array}$ & $\begin{array}{l}\text { Transpiration rate } \\
\left(\mathrm{mmol} \mathrm{H}_{2} \mathrm{O} \mathrm{m}-^{2} s^{-1}\right)\end{array}$ & $\begin{array}{c}\text { Water-use efficiency } \\
\left(\mu \mathrm{mol} \mathrm{CO}{ }_{2} \mu \mathrm{mol}^{-1} \mathrm{H}_{2} \mathrm{O}\right)\end{array}$ \\
\hline $0 \%$ & $11.44 \pm 0.04 \mathrm{a}$ & $21.36 \pm 10.93$ & $0.59 \pm 0.28$ & $22.53 \pm 8.15 c$ \\
\hline $25 \%$ & $11.29 \pm 0.16 \mathrm{a}$ & $17.71 \pm 3.07$ & $0.46 \pm 0.08$ & $25.40 \pm 4.40 \mathrm{c}$ \\
\hline $50 \%$ & $11.37 \pm 0.08 \mathrm{a}$ & $25.07 \pm 13.75$ & $0.76 \pm 0.38$ & $18.01 \pm 6.34 \mathrm{c}$ \\
\hline $75 \%$ & $10.83 \pm 0.18 b$ & $4.49 \pm 1.34$ & $0.14 \pm 0.04$ & $99.70 \pm 4.97 \mathrm{a}$ \\
\hline $100 \%$ & $11.10 \pm 0.05 \mathrm{ab}$ & $13.88 \pm 5.39$ & $0.40 \pm 0.15$ & $62.40 \pm 5.98 b$ \\
\hline M.S. & 0.18 & 0.00 & 0.16 & 3682.90 \\
\hline$F$ value & 11.31 & 2.40 & 2.84 & 88.50 \\
\hline $\operatorname{Pr}>F$ & 0.0010 & 0.1188 & 0.0825 & $<0.0001$ \\
\hline
\end{tabular}
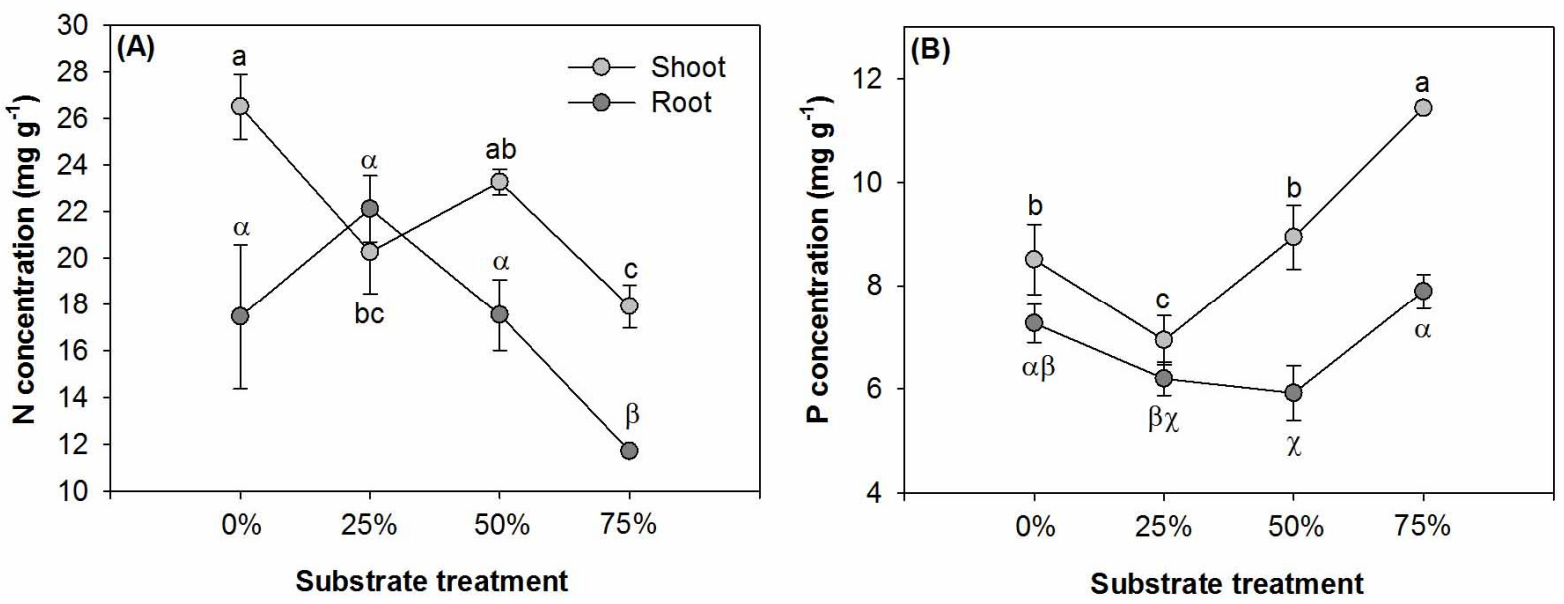

Fig. 3. N (A) and P (B) concentrations in shoot and root parts of pepper (Capsicum annuum L.) plants cultured in the media mixed with commercial peat and fresh spent mushroom substrate (SMS) in proportions of 0\% (control), 25\%, 50\%, and 75\%. Different letters indicate significant difference in Tukey test at $\alpha=0.05$. Letters of $a, b$, and $c$ indicate difference for shoot part; letters of $\alpha, \beta$, and $\chi$ indicate difference for root part 

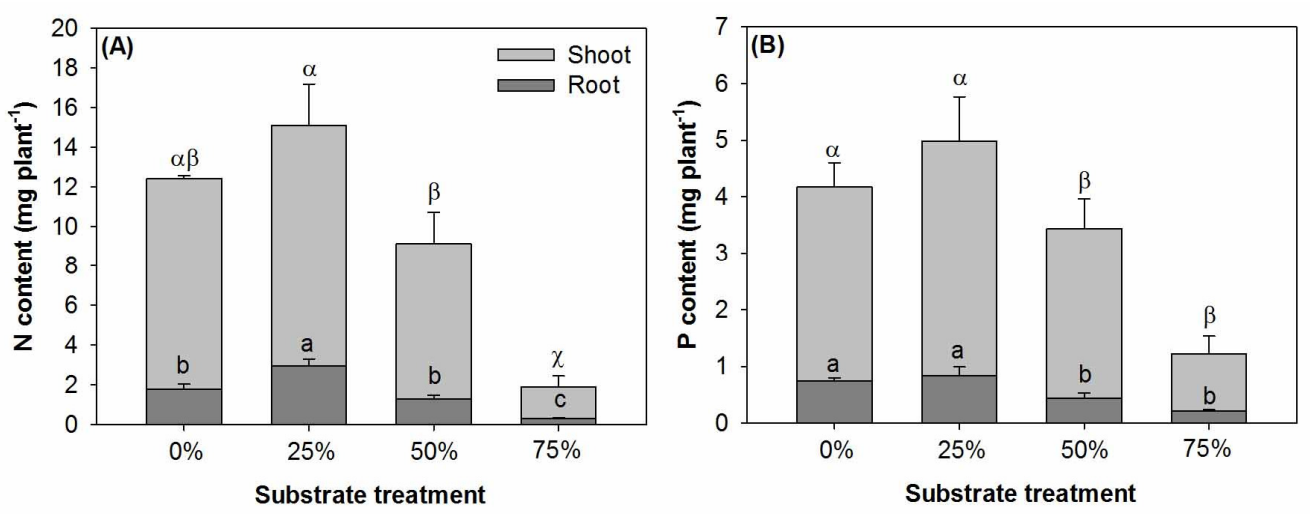

Fig. 4. N (A) and P (B) contents in shoot and root parts of pepper (Capsicum annuum L.) plants cultured in the media mixed with commercial peat and fresh spent mushroom substrate (SMS) in proportions of $0 \%$ (control), 25\%, 50\%, and 75\%. Different letters indicate significant difference in Tukey test at $\alpha=0.05$. Letters of $\alpha, \beta$, and $\chi$ indicate difference for shoot part; letters of a, $b$, and $c$ indicate difference for root part

concentration showed a decreasing trend from $0 \%$ to the $50 \%$ treatment then increased by $33 \%$ in the $75 \%$ treatment $(\mathrm{P}=0.0013)$ (Fig. 3B).

Both $\mathrm{N}$ and $\mathrm{P}$ contents tended to be highest in the $25 \%$ treatment among all treatments with different proportions of SMS (Fig. 4). Compared to shoot N content in the $25 \%$ treatment, that in the $50 \%$ and $75 \%$ treatments declined by $35 \%$ and $87 \%$, respectively $(P<0.0001)$ (Fig. $4 \mathrm{~A})$. Root $\mathrm{N}$ content increased by $68 \%$ in the $25 \%$ treatment than in the control $(\mathrm{P}<0.0001)$ (Fig. 4A). Compared to $\mathrm{N}$ content in the $25 \%$ treatment, that in the $50 \%$ and $75 \%$ treatments declined by $56 \%$ and $89 \%$, respectively. Compared to shoot $\mathrm{P}$ content in the $25 \%$ treatment, that in the $50 \%$ and $75 \%$ treatments declined by $28 \%$ and $76 \%$, respectively $(\mathrm{P}=0.0003)$ (Fig. 4B). Compared to root $\mathrm{P}$ content in the $25 \%$ treatment, that in the $50 \%$ and $75 \%$ treatments declined by $47 \%$ and $74 \%$, respectively $(P=0.0003)$.

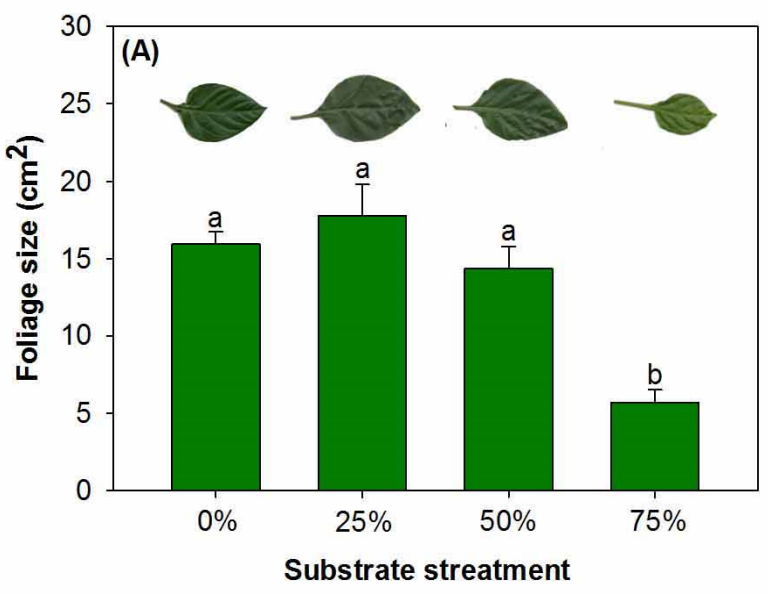

\section{Foliar area and green degree}

Foliar area did not change among the treatments of $0 \%$, $25 \%$, and $50 \%$ treatments $(P<0.0001)$ (Fig. 5A). Foliar area in the $75 \%$ treatment declined by $68 \%$ than that in the $25 \%$ treatment. Foliar green degree was not statistically different among the treatments $(F=2.55 ; P=0.1291)$. Foliar green degree ranged from $89.06 \pm 14.30$ to $104.62 \pm 5.55$ and had a negative relationship with shoot $\mathrm{N}$ concentration (Fig. $5 \mathrm{~B}$ ).

\section{Carbohydrate content and foliar enzyme activity}

Soluble sugar content was not statistically different among treatments in either shoot $(F=0.68 ; P=0.5873)$ or root $(F=1.38 ; P=0.3161)$ parts. Soluble sugar content in shoot ranged from $208.79 \mathrm{mg} \mathrm{g}^{-1}$ to $255.89 \pm 35.45 \mathrm{mg} \mathrm{g}^{-1}$, while that in root ranged from $88.66 \mathrm{mg} \mathrm{g}^{-1}$ to $158.43 \pm 55.81 \mathrm{mg} \mathrm{g}^{-1}$. In contrast, starch content had a significant response to SMS substrate proportion

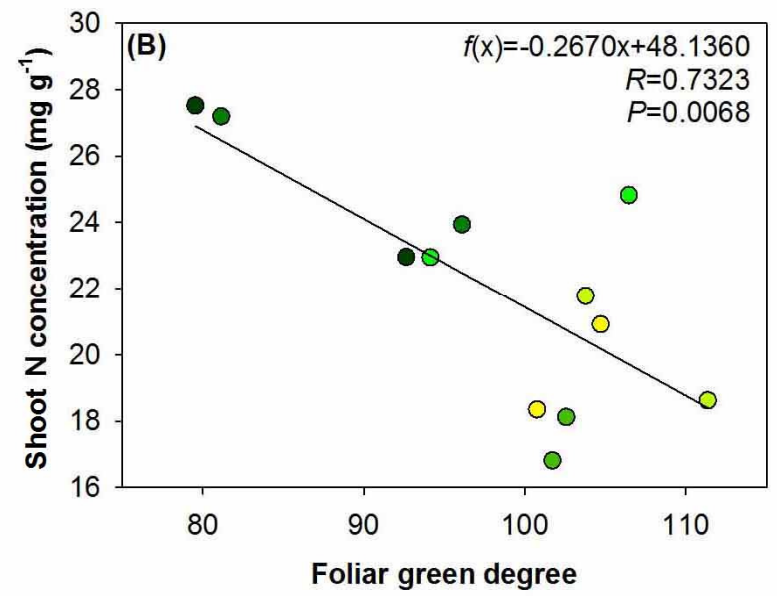

Fig. 5. A: the area of leaves in pepper (Capsicum annuum L.) plants cultured in the media mixed with commercial peat and fresh spent mushroom substrate (SMS) in proportions of $0 \%$ (control), 25\%, 50\%, and 75\%. Different letters indicate significant difference in Tukey test at $\alpha=0.05$. B: the linear correlation between foliar green degree and shoot $\mathrm{N}$ concentration 
Table 4. Starch content and foliar enzyme activity in pepper plants in fresh spent mushroom substrate mixed with commercial peat in different proportions $(\mathrm{v} / \mathrm{v})$

\begin{tabular}{|c|c|c|c|c|}
\hline Treatment & Shoot starch $\left(\mathrm{mg} \mathrm{g}^{-1}\right)$ & Root starch $\left(\mathrm{mg} \mathrm{g}^{-1}\right)$ & Foliar ACP $\left(\mu \mathrm{g} \mathrm{NPP} \mathrm{g}{ }^{-1} \mathrm{FW} \mathrm{min}^{-1}\right)$ & Foliar GS $\left(\mathrm{A} \mu \mathrm{g}^{-1}\right.$ protein $\left.\mathrm{h}^{-1}\right)$ \\
\hline $0 \%$ & $69.17 \pm 0.71 \mathrm{ab}$ & $138.77 \pm 38.42 \mathrm{a}$ & $45.21 \pm 2.05 a$ & $6.71 \pm 1.06 \mathrm{a}$ \\
\hline $25 \%$ & $98.04 \pm 23.31 \mathrm{a}$ & $80.95 \pm 6.38 b$ & $30.36 \pm 0.51 b$ & $10.82 \pm 3.65 a$ \\
\hline $50 \%$ & $48.52 \pm 5.95 b$ & $72.93 \pm 6.32 b$ & $35.61 \pm 2.61 \mathrm{ab}$ & $8.34 \pm 2.15 a$ \\
\hline $75 \%$ & $71.45 \pm 5.04 \mathrm{ab}$ & $88.75 \pm 7.86 \mathrm{ab}$ & $41.47 \pm 9.24 \mathrm{ab}$ & $12.59 \pm 2.17 \mathrm{a}$ \\
\hline M.S. & 1237.62 & 2638.53 & 128.10 & 0.00 \\
\hline$F$ value & 7.33 & 5.84 & 4.75 & 3.07 \\
\hline $\operatorname{Pr}>F$ & 0.0110 & 0.0205 & 0.0348 & 0.0911 \\
\hline
\end{tabular}

Table 5. The Pearson correlation between the chemical properties and nutrient concentrations and contents in pepper plants $(n=12)$

\begin{tabular}{ccccccccccc}
\hline Substrate & \multicolumn{3}{c}{$\mathrm{N}$ concentration } & \multicolumn{2}{c}{ P concentration } & \multicolumn{2}{c}{ N content } & \multicolumn{2}{c}{ P content } \\
\hline & & Shoot & Root & Shoot & Root & Shoot & Root & Shoot & Root \\
\hline \multirow{2}{*}{$\mathrm{NH}_{4}{ }^{+}-\mathrm{N}$} & $R$ & 0.6667 & 0.7342 & -0.8638 & -0.5300 & 0.8964 & 0.7616 & 0.8489 & 0.8201 \\
& $P$ & 0.0178 & 0.0056 & 0.0003 & 0.0763 & $<0.0001$ & 0.0040 & 0.0005 & 0.0011 \\
& $R$ & 0.5128 & 0.6565 & -0.7391 & -0.1505 & 0.8137 & 0.7824 & 0.7401 & 0.8765 \\
$\mathrm{NO}_{3}-\mathrm{N}$ & $P$ & 0.0882 & 0.0204 & 0.0060 & 0.6407 & 0.0013 & 0.0026 & 0.0059 & 0.0002 \\
& $R$ & -0.7252 & -0.5981 & 0.7125 & 0.1852 & -0.8456 & -0.6923 & -0.7751 & -0.8541 \\
$\mathrm{PO}_{4}{ }^{3-}-\mathrm{P}$ & $P$ & 0.0076 & 0.0399 & 0.0093 & 0.5644 & 0.0005 & 0.0126 & 0.0031 & 0.0004 \\
& $R$ & -0.7326 & -0.6881 & 0.7841 & 0.3710 & -0.8538 & -0.7212 & -0.7820 & -0.8240 \\
$\mathrm{pH}$ & $P$ & 0.0067 & 0.0134 & 0.0025 & 0.2351 & 0.0004 & 0.0081 & 0.0027 & 0.0010 \\
& $R$ & -0.7535 & -0.6212 & 0.7070 & 0.2486 & -0.8458 & -0.6801 & -0.7791 & -0.8236 \\
& $\mathrm{EC}$ & $P$ & 0.0047 & 0.0311 & 0.0101 & 0.4359 & 0.0005 & 0.0149 & 0.0028 & 0.0010 \\
& & &
\end{tabular}

Note: The light gray color of the cell indicates positive correlation; the dark gray color of the cell indicates negative correlation.

treatments (Table 4). Shoot starch content tended to be highest in the $25 \%$ treatment which was higher than that in the $50 \%$ treatment by $102 \%$. However, root starch content tended to be highest in the control which was higher than that in the other treatments by about $70 \%$. Foliar ACP activity also tended to be highest in the control, which was higher by $49 \%$ compared to that in the $25 \%$ treatment (Table 4). Foliar GS activity did not change among treatments.

\section{Correlation analysis}

Generally, both substrate $\mathrm{NH}_{4}^{+}-\mathrm{N}$ and $\mathrm{NO}_{3}^{-}-\mathrm{N}$ concentrations were positively correlated with $\mathrm{N}$ and $\mathrm{P}$ parameters except for $\mathrm{P}$ concentrations (Table 5). In contrast, substrate $\mathrm{PO}_{4}^{3-}-\mathrm{P}$ concentration, $\mathrm{pH}$, and EC were positively correlated with shoot $\mathrm{P}$ concentration but negatively correlated with other nutrient parameters.

\section{Discussion}

\section{Growth and biomass accumulation}

Using SMC as the component of the mixture in substrate, a proportion of $20 \sim 30 \%$ could result in better responses of growth and biomass for shrubs (Chong et al., 1994), rough lemon (Citrus jambhiri L.) (Khan et al., 2006), and horticultural plants (Medina et al., 2009; Gonani $e t$ al., 2011; Kwack et al., 2012). Although we used fresh SMS as one component in the substrate, we also found that the SMS proportion of $25 \%$ can result in better height and diameter growth (Table 2) and greater shoot and root biomass accumulation (Fig. 2A). Former results, as well as those found in our study, together suggest that SMS, no matter composted or fresh, is not suitable to be used as the main component in the substrate for horticultural plant culture. Furthermore, using pepper as the material Marín $e t$ al. (2014) reported that the highest stem length (seedling height) and diameter were measured to be $15.13 \mathrm{~cm}$ and $3.06 \mathrm{~mm}$, respectively, in response to SMC. These values were both lower than those in the $25 \%$ treatment in our study (Table 2). In addition, the total dry weight in our study $(0.73 \pm 0.07 \mathrm{~g})$ was also greater than that $(0.50 \mathrm{~g})$ in Marín et al. (2014). The promotion of SMS substrate on shoot parameters was also supported by R/S, which was not statistically different among the control and the 25\% treatment but higher ratio in the $75 \%$ treatment (Fig. 2B). This suggests that the substrate will not drive dry mass allocated to roots unless the SMS proportion was over $50 \%$. Therefore, the $25 \%$ proportion of fresh SMS in the substrate in our study can be recommended for the practical use to improve growth and biomass accumulation in pepper plants.

\section{Fruiting performance}

In line with growth and biomass results, our results also showed that both fruit number and fruit weight showed best performance in the $25 \%$ treatment (Table 2). (Szmidt and Chong, 1995; Gonani et al., 2011). In agreement with our results, Ahlawat et al. (2007) found that the involvement of SMC composting for 12 months in the substrate can also enhance the yield of pepper plants. Gonani et al. (2011) found more fruits out in the cucumber (Cucumis sativus) plants receiving the substrate of 25\% (v/v) SMC than that of $25 \%$ SMC. The addition of SMS 
234

to the substrate can promote the fruit quality of pepper plants except for vitamin C content (Eudoxie et al., 2014). Other studies revealed that the soils amended by SMS can be effective in promoting yield and quality of melon (Nguyen and Wang, 2016) and maize (Wuest et al., 1995). Therefore, the promotion of fruit yield in crop plants appeared to be a general effect by SMS addition to substrate. However, when the SMS proportion in the substrate increased to excess $50 \%$ the boll number significantly declined compared to the control (Table 2). Therefore, the SMS proportion in the substrate cannot affect boll generation unless it occupied the half volume. The $25 \%$ proportion of SMS in the substrate did not show any superiority in boll numbers; hence this proportion cannot be recommended for the potential of flowing and yield in pepper plants.

\section{The photosynthetic production and gas exchange}

In this study, the shoot starch content tended to be highest in the $25 \%$ treatment, where root starch content was lower than the control (Table 4). These results suggest that seedlings in this treatment would allocate more photosynthetic productions in the shoot part to support the growth, biomass, and fruiting quality. Because we did not find any response of sugars, it cannot be put forward that SMS substrate had any effect on starch hydrolyzation into sugars. However, photosynthetic rate did not change in the substrates where the SMS proportion was lower than $75 \%$ (Table 3). Because SMS is of high risk of EC, the high proportion of SMS in the substrate $(\sim 75 \%)$ may have interrupted the photosynthesis through high ion concentration (Szmidt and Chong, 1995; Gonani et al., 2011). Even the rhizosphere-condition in the $75 \%$ treatment had unlikely caused the salinity stress on pepper plants because no gas exchange responded (Guo et al., 2016). Furthermore, we suspect the 100\% SMS substrate has caused severe saline stress because nearly all seedlings died off (Fig. 1). The high WUE in the $75 \%$ treatment mainly resulted from the relatively lower transpiration rate in spite it was not statistically different from that in other treatments. As a photosynthetic organ, the area of leaves responded to SMS substrate with the same trend of photosynthetic rate. This was because the foliar area was related with the photosynthetic rate and the 25\% proportion of SMS in the substrate failed to affect the foliar area. In contrast, Marín et al. (2014) reported that pepper plants in the treatment with best growth performance also had largest leaves. The foliar area in our study was about a quarter of that in Marín et al. (2014). This may be because seedlings in our study were cultured under artificial lighting and the PPFD of around $70 \mu \mathrm{mol} \mathrm{m} \mathrm{m}^{-2} \mathrm{~s}^{-1}$ might be insufficient for the growth of large leaves.

\section{Nutrient availability}

The fresh SMS used in this study had less extractable N concentration but higher available P concentration than the commercial peat (Table 1). In other studies, both $\mathrm{NH}_{4}^{+}{ }^{+} \mathrm{N}$ and $\mathrm{NO}_{3}{ }^{-} \mathrm{N}$ concentrations were much higher than those in ours. For example, the $\mathrm{NH}_{4}{ }^{+}-\mathrm{N}$ was recorded to be 2,800 $\mathrm{mg} \mathrm{kg}^{-1}$ (Szmidt and Chong, 1995), $186 \mathrm{mg} \mathrm{kg}$ ', $327 \mathrm{mg} \mathrm{kg}^{-1}$ (Paredes et al., 2016), and $250 \mathrm{mg} \mathrm{kg}^{-1}$ (Paula et al., 2017). The $\mathrm{NO}_{3}-\mathrm{N}$ was recorded to be $5,800 \mathrm{mg} \mathrm{kg}^{-1}$
(Szmidt and Chong, 1995), $53 \mathrm{mg} \mathrm{kg}{ }^{-1}$, and $81 \mathrm{mg} \mathrm{kg}^{-1}$ (Paredes et al., 2016). The composting process can increase the extractable $\mathrm{N}$ concentration by at least $100 \%$ (Paula $e t$ al., 2017). Fresh mushroom had low concentration of available $\mathrm{N}$ because it had been composted. Available $\mathrm{P}$ concentration in the fresh SMS in our study was found to be about three-fold higher than that in the commercial peat (Table 1). Our results about available P concentration were higher than that reported by Unal (2015) (13.79 206.84 $\left.\mathrm{mg} \mathrm{kg}{ }^{-1}\right)$ but much lower than that reported by Sönmez et al. (2016) $\left(25,280 \sim 28,280 \mathrm{mg} \mathrm{kg}^{-1}\right)$ and that by Paredes $e t$ al. (2016) $\left(3,740 \sim 6,800 \mathrm{mg} \mathrm{kg}^{-1}\right)$. Therefore, the fresh SMS in our study can be generally characterized by poor $\mathrm{N}$ availability and moderate $P$ availability.

Compared to the control, shoot $\mathrm{N}$ concentration declined in the $25 \%$ treatment where root $\mathrm{N}$ concentration tended to increase but results were not statistically different (Fig. 3A). Regarding that the foliar GS activity was not different among treatments (Table 4) while biomass was greatest in the $25 \%$ treatment, it can be speculated that $\mathrm{N}$ was assimilated in root and utilized in shoot in the substrate with 25\% SMS. The difference of N and P content among treatments was similar to that of biomass and starch content. Therefore, the positive relationship between substrate available $\mathrm{N}$ and $\mathrm{N}$ and $\mathrm{P}$ should be the result of promotion on carbohydrate production and thereafter biomass accumulation. In addition, the negative relationship between available $\mathrm{N}$ concentration in the substrate and $\mathrm{P}$ concentration was the result of $\mathrm{P}$ dilution by biomass increment. It was summarized that the high $\mathrm{pH}$ value and EC in SMS can impact its usage as the substrate for horticultural plants (Szmidt and Chong, 1995; Gonani et al., 2011). In our study, $P$ concentration increased with the increase of SMS proportion in the substrate (Fig. 3B). This trend concurs with that of available $\mathrm{P}$ concentration in the substrate with increasing proportion of SMS, which also caused increasing $\mathrm{pH}$ and EC (Table 1). Therefore, the negative relationship between available $\mathrm{P}$ concentration in the substrate and $\mathrm{N}$ concentration and $\mathrm{N}$ and $\mathrm{P}$ contents should be result of increasing $\mathrm{pH}$ and $\mathrm{EC}$ with the accumulating of SMS in the substrate.

\section{Conclusions}

With the increase of fresh SMS in the substrate mixing with the commercial peat, available $\mathrm{N}$ concentration declined but extractable $\mathrm{P}, \mathrm{pH}$ and $\mathrm{EC}$ all increased. These gradient changes were mainly accompanied by the unimodal pattern of response of pepper plants in response to different proportions of SMS. As a result, the 25\% proportion of SMS in the substrate was found to be the best treatment because it induced best height and diameter growth, biomass accumulation in shoot and root parts, fruit number and weight. These results can be attributed to by the accumulation of starch in shoot of seedlings under the $25 \%$ SMS condition. The SMS substrate did not affect photosynthetic rate and gas exchange in the proportion lower than 75\%. High proportion of SMS caused the declines of $\mathrm{N}$ concentration and $\mathrm{N}$ and $\mathrm{P}$ contents. Seedlings in the $100 \%$ SMS substrate nearly died out. Therefore, fresh SMS cannot be directly used as the substrate for the culture of pepper plants. According to 
findings in our study and others, fresh SMS was recommended to be mixed in the proportion of $25 \%$ with commercial peat for the culture of horticultural plants.

\section{References}

Ahlawat OP, Sagar MP, Raj D, Rani CI, Gupta P, Vijay B (2007). Effect of spent mushroom substrate on yield and quality of capsicum. Indian Journal of Horticulture 64(4):430-434.

Bustamante MA, Paredes C, Moral R, Agulló E, Pérez-Murcia MD, Abad M (2008). Composts from distillery wastes as peat substitutes for transplant production. Resources Conservation and Recycling 52(5):792-799.

Chen JT, Lin MJ, Huang JW (2015). Efficacy of spent blewit mushroom compost and Bacillus aryabhattai combination on control of Pythium damping-off in cucumber. Journal of Agricultural Science 153:1257-1266.

Chong C, Cline RA, Rinker DL (1994). Bark- and peat-amended spent mushroom compost for containerized culture of shrubs. HortScience 29(7):781-784.

Curtin JS, Mullen GJ (2007). Physical properties of some intensively cultivated soils of Ireland amended with spent mushroom compost. Land Degradation and Development 18(4):355-368.

Eudoxie G, Martin M, Mohammed M (2014). Substrate evaluation on postharvest quality of sweet pepper (Capsicum annuumm L.) fruit under gravity fed fertigation. Acta Horticulturae 1047:87-92.

FAO (2016). FAOSTAT. Accessed on 3 January 2018. Available at: http://www.fao.org/faostat/en/?\#data/QC

Gonani Z, Riahi H, Sharifi K (2011). Impact of using leached spent mushroom compost as a partial growing media for horticultural plants. Journal of Plant Nutrition 34(3):337-344.

Guo P, Jin H, Wei HX, Li LL, Bao YJ (2016). Fine root growth and water use efficiency in alfalfa (Medicago sativa L. cv. Gongnong No.1) planted along a salinity gradient in coastal area of Dalian, Northeast China. Soil Science and Plant Nutrition 62(2):164 172.

Kadiri M, Mustapha Y (2010). The use of spent mushroom substrate of Lentinus subnudus (Berke) as a soil conditioner for vegetables. Bayero Journal of Pure and Applied Sciences 3:16-19.

Kandemir D, Peksen A, Ozer H, Uzun S (2009). The effect of spent mushroom compost with some other transplant production media on seedling quality of Broccoli (Brassica oleracea var. italica) and Kale (Brassica acephala L.). Acta Horticulturae 830:377-384.

Kato K, Matsushima U, Muto Y, Tatsuzawa F, Okada M (2013). Effects of application of spent Shiitake substrates in farmlands damaged by the great East Japan earthquake on soil conditions and sweet corn growth and Yield. Horticulture Journal 12:381-387.

Khan MM, Khan MA, Abbas M, Jaskani MJ, Ali MA, Abbas H (2006). Evaluation of potting media for the production of rough lemon nursery stock. Pakistan Journal of Botany 38(3):623-629.

Kwack Y, Song JH, Shinohara Y, Maruo T, Chun C (2012). Comparison of six spent mushroom composts as growing media for transplant production of lettuce. Compost Science and Utilization 20(2):92-96.

Li XW, Gao Y, Wei HX, Xia HT, Chen QX (2017). Growth, biomass accumulation and foliar nutrient status in fragrant rosewood (Dalbergia odorifera T.C. Chen) seedlings cultured with conventional and exponential fertilizations under different photoperiod regimes. Soil Science and Plant Nutrition 63(2):153162.

Marín F, Diánez F, Santos M, Carretero F, Gea FJ, Castaneda C, Navarro MJ, Yau JA (2014). Control of Phytophthora capsici and Phytophthora parasitica on pepper (Capsicum annum L.) with compost teas from different sources, and their effects on plant growth promotion. Phytopathologia Mediterranea 53(2):216-228.

Medina E, Paredes C, Pérez-Murcia MD, Bustamante MA, Moral R (2009). Spent mushroom substrates as component of growing media for germination and growth of horticultural plants. Bioresource Technology 100:4227-4232.

Nakatsuka H, Oda M, Hayashi Y, Tamura K (2016). Effects of fresh spent mushroom substrate of Pleurotus ostreatus on soil micromorphology in Brazil. Geoderma 269:54-60.

Nguyen VT, Wang CH (2016). Effects of organic materials on growth, yield, and fruit quality of honeydew melon. Communication in Soil Science and Plant Analysis 47(4):495-504.

Paredes C, Medina E, Bustamante MA, Moral R (2016). Effects of spent mushroom substrates and inorganic fertilizer on the characteristics of a calcareous clayey-loam soil and lettuce production. Soil Use and Management 32(4):487-494.

Paula FS, Tatti E, Abram F, Wilson J, O'Flaherty V (2017). Stabilisation of spent mushroom substrate for application as a plant growth-promoting organic amendment. Journal of Environment Management 196:476-486.

Peregrina F, Larrieta C, Colina M, Mariscal-Sancho I, Martín I, Martínez-Vidaurre JM, García-Escudero E (2012). Spent mushroom substrates influence soil quality and nitrogen availability in a semiarid vineyard soil. Soil Science Society of America Journal 76(5):1655-1666.

Rhoads FM, Olson SM (1995). Crop production with mushroom compost. Soil and Crop Science Society of Florida Proceeding 54:53-57.

Ribeiro HM, Romero AM, Pereira H, Borges P, Cabral F, Vasconcelos $\mathrm{E}$ (2007). Evaluation of a compost obtained from forestry wastes and solid phase of pig slurry as a substrate for seedlings production. Bioresource Technology 98:3294-3297.

Segarra G, Casanova E, Borrero C, Avilés M, Trillas I (2007). The suppressive effects of composts used as growth media against Botrytis cinerea in cucumber plants. European Journal of Plant Pathology 117(4):393-402.

Semple KT, Reid BJ, Fermor TR (2001). Impact of composting strategies on the treatment of soils contaminated with organic pollutants. Environmental Pollution 112(2):269-283.

Soccol CR, Vandenberghe LPS (2008). Overview of applied solid-state fermentation in Brazil. Biochemical Engineering Journal 13(2):205-218.

Sönmez I, Kalkan H, Demir H (2016). Effects of spent mushroom compost on seedling quality and nutrient contents of eggplants (Solanum melongena) grown in different growing media. Acta Horticulturae 1142:403-408. 
236

Stewart DPC, Cameron KC, Cornforth IS, Sedcole JR (1998). Effect of spent mushroom substrate on soil physical conditions and plant growth in an intensive horticultural system. Australian Journal of Soil Research 36(6):899-9212.

Szmidt RAK, Chong C (1995). Uniformity of spent mushroom substrate (SMS) and factors in applying recommendations for use. Compost Science and Utilization 3(1):6471.

Tam NV, Wang CH (2015). Use of spent mushroom substrate and manure compost for honeydew melon seedlings. Journal of Plant Growth Regulation 34(2):417-424.

Unal M (2015). The utilization of spent mushroom compost applied at different rates in tomato (Lycopersicon esculentum Mill.) seedling production. Emirates Journal of Food and Agriculture 27(9):692697.

Wang Z, Zhao Y, Wei HX (2017). Chitosan oligosaccharide addition affects current-year shoot of post-transplant Buddhist pine (Podocarpus macrophyllus) seedlings under contrasting photoperiods. iForest - Biogeosciences and Forestry 10:715-721.

Wei HX, Ren J, Zhou JH (2013). Effect of exponential fertilization on growth and nutritional status in Buddhist pine (Podocarpus macrophyllus [Thunb.] D. Don) seedlings cultured in natural and prolonged photoperiods. Soil Science and Plant Nutrition 59:933941.
Wei HX, Xu CY, Ma LY, Duan J, Jiang LN, Ren J (2014). Effect of late-season fertilization on nutrient reserves and carbohydrate accumulation in bareroot Larix olgensis seedlings. Journal of Plant Nutrition 37:279-293.

Wuest PJ, Fahy HK, Fahy J (1995). Use of spent mushroom substrate (SMS) for corn (Maize) production and its effect on surface water quality. Compost Science and Utilization 3(1):46-54.

Zhang RH, Duan ZQ, Li ZQ (2012). Use of spent mushroom substrate as growing media for tomato and cucumber seedlings. Pedosphere 22(3):333-342.

Zhang JH, Tian GM, Zhou GD, He MM, Wang F, Yao JH (2013). Evaluation of organic solid wastes composts as peat substitutes for seedling production. Journal of Plant Nutrition 36:1780-1794.

Zhao Y, Wang Z, Wei HX, Bao YJ, Guo P (2017). Effect of prolonged photoperiod on morphology, biomass accumulation and nutrient utilization in post-transplant Taxus cuspidata seedlings. Pakistan Journal of Botany 49(4):1285-1290.

Zhu KY, Liu HC, Wei HX, Zhou JH, Zou QC, Ma GY, Zhang JQ (2016). Prediction of nutrient leaching from culture of containerized Buddhist pine and Japanese maple seedlings exposed to extended photoperiod. International Journal of Agriculture and Biology 18:425-434. 